\title{
Pengenalan Budidaya Azolla untuk Mendukung Pengembangan Pertanian Organik
}

\author{
Jauhari Syamsiyah*, Ganjar Herdiansyah, Sri Hartati, Suryono \\ Program Studi Ilmu Tanah, Fakultas Pertanian, Universitas Sebelas Maret \\ *Corresponding author: ninukts@staff.uns.ac.id
}

\begin{abstract}
ABSTRAK
Azolla merupakan tumbuhan paku air dengan kelebihan memiliki sifat yang cepat dalam proses berkembang biak serta dapat digunakan sebagai pupuk organik dalam bentuk kompos atau pupuk hijau, namun belum banyak dikenal dikalangan petani, khususnya kelompok Tani Makmur dan Margo Mulyo di dusun Nayan, Nangsri, Kebakkramat. Permasalahan utama pada kelompok tani tersebut adalah minimnya pengetahuan dan informasi mengenai budidaya Azolla dan pemanfaatan azolla sebagai sumber pupuk organik serta penerapan pupuk organik ini pada lahan pertanian. Tujuan dari kegiatan ini adalah mengenalkan Azolla ke kelompok tani, melatih budidaya Azolla dan mengevaluasi penerimaan petani terhadap pengembangan pertanian organik yang ramah lingkungan, dan mengurangi ketergantungan penggunaan pupuk anorganik atau sintetik dengan memanfaatkan Azolla sebagai sumber daya alam lokal. Kegiatan yang dilakukan dalam melaksanakan pengabdian ini antara lain : Survei lokasi dan waktu pelaksanaan, Edukasi/paparan dan sosialisasi tentang manfaat azolla, Pelatihan budidaya dan pendampingan aplikasi azolla, Focus Grup Discussion (FGD). Metode pengabdian dilakukan melalui penyuluhan, pelatihan dan evaluasi kegiatan dalam pengembangan pertanian organik yang ramah lingkungan menggunakan sumberdaya lokal yaitu azolla. Pengetahuan petani tentang Azolla dan manfaatnya sebagai sumber pupuk organik sebelum dilakukan penyuluhan masih rendah atau $<20 \%$ yang baru mengetahui manfaat dari azolla. Setelah dilakukan kegiatan, pengetahuan dan pemahaman petani tentang potensi dan manfaat budidaya azolla meningkat serta ketertarikan petani terhadap budidaya azolla secara mandiri mencapai 90\%. Azolla merupakan sumber pupuk organik yang dapat menekan penggunaan pupuk anorganik atau sintetik.
\end{abstract}

Kata kunci : azolla, pelatihan, penyuluhan, pupuk organik

\section{ABSTRACT}

Azolla is a water fern plant with the advantage of being fast in the breeding process and can be used as organic fertilizer in the form of compost or green manure but it is not widely known among farmers, especially the Tani Makmur and Margo Mulyo in the Nayan village, Nangsri, Kebakkramat. The main problems that arise from these farmers are lack of knowledge and information about Azolla cultivation and the use of azolla as a source of organic fertilizer and the application of this organic fertilizer to agricultural land. The purpose of this activity is to introduce Azolla to farmer groups, train Azolla cultivation and evaluate farmers 'acceptance of the development of environmentally friendly organic agriculture and dependence on the use of inorganic or synthetic fertilizers by utilizing azolla asl a local natural resources. The methods used in carrying out this service include: 1) Site survey and time of implementation, 2) Education/exposure and socialization of the benefits of azolla, 3) Cultivation training and mentoring Azolla application, 4) Focus Group Discussion (FGD). The activities of community service are carried out through counseling, training and evaluation of activities in the development of environmentally friendly organic agriculture using local resources, namely Azolla. Farmers' knowledge about Azolla and its benefits as a source of organic fertilizer before extension activities was still low or $<20 \%$ who just found out the benefits of Azolla. After this community service activity, farmers 'knowledge and understanding of the potential and benefits of azolla cultivation increased and farmers' interest in cultivating azolla independently reached $90 \%$. Azolla is a source of organic fertilizer that can reduce the use of inorganic or synthetic fertilizers.

Key word : azolla, counseling, organic fertilizer, training 


\section{PENDAHULUAN}

Peraturan Menteri Pertanian No. 2 tahun 2006 menjelaskan bahwa pupuk organik merupakan pupuk yang berasal dari tanaman dan/atau hewan yang sudah melalui proses rekayasa, yang bertujuan untuk memperbaiki sifat tanah baik itu kimia, fisika maupun biologi. Pupuk organik dapat berbentuk padat ataupun cair. Jenis dan varian dari pupuk organik sangat beragam, yang berasal dari kotoran hewan, hijauan atau campuran kotoran hewan dan hijauan.

Perkembangan teknologi pupuk organik semakin pesat. Karena dampak dari pemakaian pupuk anorganik yang berlebihan sehingga menimbulkan permasalahan dari rusaknya ekosistem, kesuburan tanah rendah, kesehatan masyarakat terganggu sampai petani yang tergantung terhadap pupuk anorganik. Untuk mengatasi permasalahan tersebut, diinstruksikan kembali pemakaian pupuk organik sebagai salah satu upaya dalam mengembangkan pertanian. Pupuk organik dapat dibedakan menjadi pupuk cair berdasarkan bentuknya, sedangkan bahan penyusunnya dapat berupa pupuk kompos, pupuk hijau dan pupuk kandang. Azolla merupakan salah satu sumber dari bahan organik yaitu sumber Nitrogen $(\mathrm{N})$ dan juga bisa dijadikan sebagai sumber pupuk hijau (Setiawati et al., 2019). Azolla sangat cocok dikembangkan oleh petani karena mudah untuk diaplikasikan dan memerlukan biaya yang murah. Azolla dipilih karena memiliki kandungan nitrogen yang tinggi dan proses terurai dalam tanah yang cepat. Aplikasi azolla yang dijadikan pupuk hijau yaitu dengan dibenamkan langsung ke dalam tanah atau dapat juga melalui proses pengomposan.

Penggunaan dan pemanfaatan azolla sebagai sumber bahan organik tanah, pada saat ini belum optimal dan belum banyak diketahui oleh masyarakat terutama para petani. Menurut (Syamsiyah et al., 2018), disamping dapat menambat nitrogen di udara, azolla memiliki kelebihan yaitu memiliki sifat yang cepat dalam proses berkembang biak. Azolla biasanya ditemukan di sawah, sungai, danau atau kolam. Azolla bagian dari tumbuhan paku air yang bersimbiosis dengan bakteri Anabaena Anabaena azollae termasuk jenis blue-green algae yang hidup menumpang tinggal dalam rongga diantara klorofil daun. Bakteri ini memiliki peran dalam menambat nitrogen bebas dari udara dengan menggunakan energi matahari sehingga dapat tersedia bagi tanaman padi
(Pereira et al., 2015). Selain itu, azolla juga mampu meningkatkan penyerapan beberapa unsur nutrisi seperti $\mathrm{Ca}, \mathrm{Mg}$, dan $\mathrm{K}$ (Bhuvaneshwari \& Kumar, 2013). Aplikasi Azolla 2,2 ton/ha dan penambahan pupuk organik pada budidaya padi sawah mampu menghasilkan pertumbuhan padi yang lebih tinggi (Soedharmo et al., 2016). Azolla memiliki beberapa potensi yaitu memiliki pertumbuhan yang cepat selama 3-6 hari dan produksi biomassa pada Azolla microphylla mencapai 1-2 $\mathrm{kg}$ per $\mathrm{m}^{2}$ bobotnya, hal ini tergantung tingkat kesuburan kolam (Supartoto et al., 2012).

Beberapa hasil penelitian membuktikan keberadaan Azolla yang adan di atas permukaan lahan sawah mampu menghemat penggunaan urea sebesar $50 \mathrm{~kg} / \mathrm{ha}$ sampai $100 \mathrm{~kg} / \mathrm{ha}$ (Jeanne, 2010). Penelitian lain juga menyatakan kombinasi perlakuan dengan melibatkan azolla dan takaran pupuk urea $60 \mathrm{~kg} \mathrm{~N} / \mathrm{ha}$ merupakan kombinasi perlakuan terbaik (Hendrarti et al., 1998). Azolla yang dimanfaatkan selama masa tanam padi dapat meningkatkan efisiensi penggunaan pupuk urea dibandingkan dengan dibenamkan sebelum tanam padi (Rasjid et al., 2000). Menurut Haryanto (2010) dalam (Gunawan, 2014) pemupukan dengan pupuk urea dapat dihemat $50 \%$ dengan cara budidaya padi dan azolla.

Tujuan dari kegiatan ini adalah mengenalkan azolla ke kelompok tani, melatih budidaya azolla dan mengevaluasi penerimaan petani terhadap pengembangan pertanian organik yang ramah lingkungan dan mengurangi ketergantungan penggunaan pupuk anorganik atau sintetis dengan memanfaatkan azolla sebagai sumber daya alam lokal. Harapan dari kegiatan ini adalah petani mau menindaklanjuti pemanfaatan azolla sebagai sumber daya alam lokal secara maksimal untuk meningkatkan pendapatan petani dan produktivitas tanaman.

\section{METODE}

Pengabdian ini dilaksanakan di Dusun Nangsri, Nayan, Kebakramat, Kabupaten Karanganyar. Kegiatan dilaksanakan pada bulan Juli-Oktober 2020.

Tahapan dalam pelaksanaan kegiatan ini meliputi:

1. Survey lokasi

Kegiatan ini dilakukan untuk menentukan lokasi kegiatan, mengurus izin kepada pihak pemerintah setempat dan berkoordinasi dengan mitra terkait kegiatan yang akan dilaksanakan. 
2. Kegiatan Utama I: Edukasi/paparan dan sosialisasi tentang azolla dan manfaatnya sebagai pengganti pupuk anorganik serta bahaya dari penggunaan pupuk anorganik yang berlebih.

Kegiatan pertama yang dilakukan meliputi penjelasan mengenai tanaman azolla, cara budidaya tanaman azolla, cara aplikasi azolla, manfaat dari tanaman azolla bagi tanaman padi serta bahaya penggunaan pupuk anorganik yang berlebih bagi tanah di daerah mitra ke Kelompok tani Tani Makmur dan Margo Mulyo.

3. Kegiatan Utama II: Pelatihan dan pendampingan aplikasi azolla pada lahan pertanian

Kegiatan ini bertujuan untuk mendampingi petani dan mengajarkan teknik budidaya Azolla. Hal ini dilakukan supaya petani bisa mandiri dalam menyediakan serta mengaplikasikan azolla pada lahan pertanian.

4. Focus Grup Discussion (FGD)

Focus Grup Discussion tentang hasil kegiatan yang telah dilakukan. Kegiatan ini bertujuan untuk mengevaluasi kekurangan dan menyimpulkan hasil kegiatan.

Kegiatan pengabdian ini menekankan pada keaktifan dan peran mitra dalam kesuksesan pelaksanaan program pengabdian. Kelompok tani yang dalam hal ini menjadi mitra dituntut untuk berperan aktif dan bersedia menindaklanjuti kegiatan serta dapat menyiapkan lokasi yang bisa digunakan untuk budidaya azolla. Evaluasi pelaksanaan kegiatan dilakukan melalui Focus Group Discussion (FGD). Monitoring seluruh kegiatan dilakukan untuk evaluasi keberlanjutan program yaitu melakukan kunjungan secara berkala ke lokasi mitra. Indikator keberhasilan kegiatan dilakukan dengan mengukur tingkat pemahaman dan ketertarikan petani terhadap azolla melalui kuesioner sebelum kegiatan dan setelah kegiatan pengabdian.

\section{HASIL DAN PEMBAHASAN}

\section{Penyuluhan}

Kegiatan ini diawali dengan melakukan koordinasi untuk menyamakan persepsi serta membuat rencana penyuluhan dan pelatihan azolla (Gambar 2). Koordinasi dilakukan antara tim pengabdian dan perwakilan Kelompok Tani Tani Makmur dan Margo Mulyo di Dusun Nayan, Nangsri, Kebakkramat. Lokasi kegiatan pengabdian dapat dilihat pada Gambar 1.

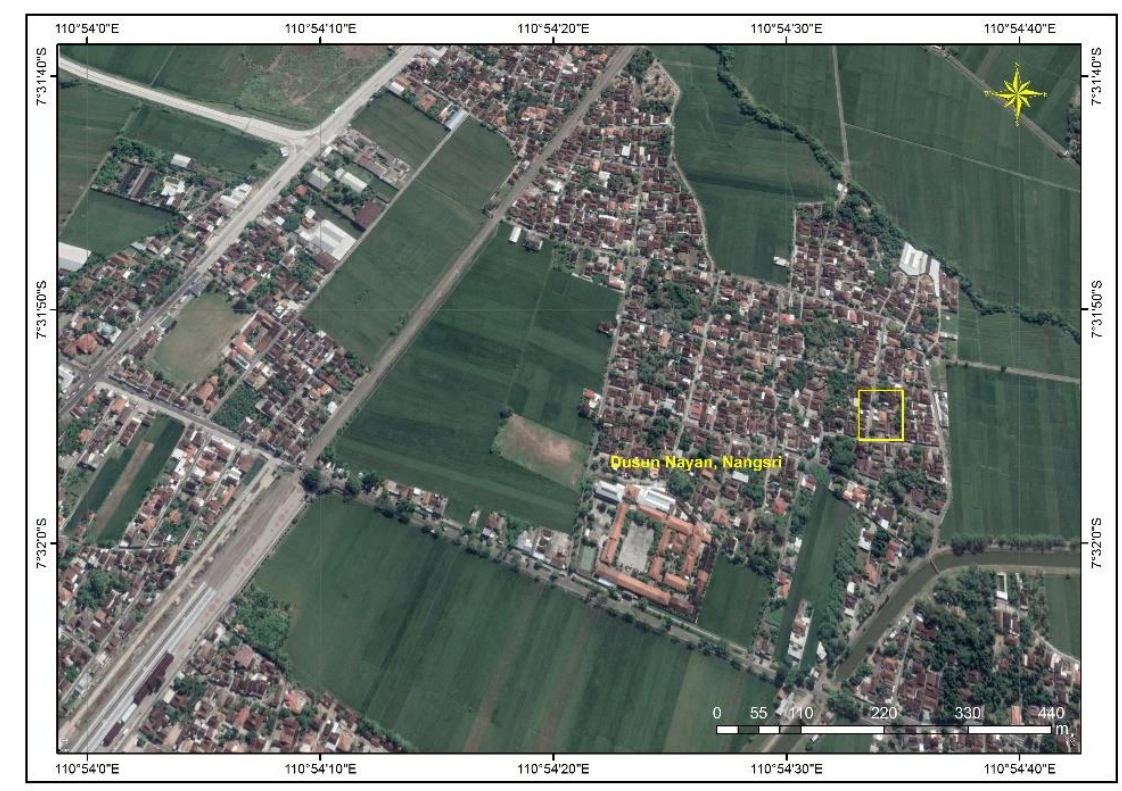

Gambar 1. Peta Lokasi Pengabdian Kepada Masyarakat

Hasil koordinasi disepakati bahwa rangkaian kegiatan ini meliputi penyuluhan tentang azolla dan pemanfaatan azolla sebagai pupuk organik, pelatihan budidaya azolla dan evaluasi hasil budidaya azolla, dan usulan untuk keberlanjutan kegiatan. 

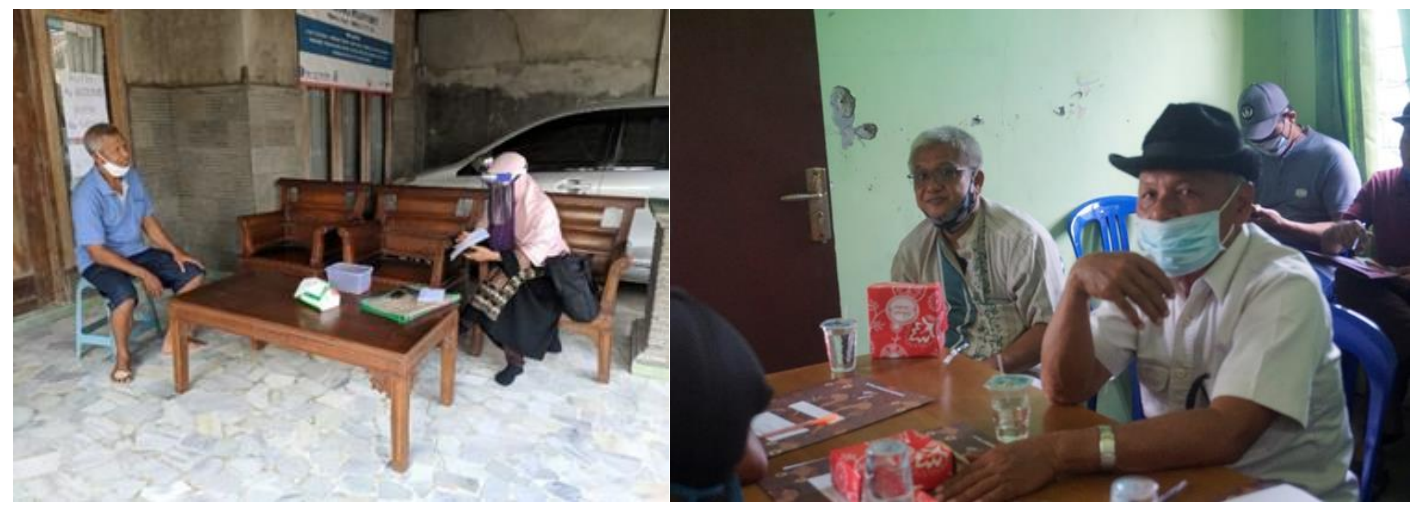

Gambar 2. Koordinasi Tim Pengabdian dengan Perwakilan Kelompok Tani

Penyuluhan dilakukan di Balai Desa Nangsri, Kebakramat, Kabupaten Karanganyar dengan menerapkan protokol kesehatan untuk mencegah penularan Covid-19. Kegiatan ini

diikuti oleh anggota Kelompok tani Margo Mulyo, Tani Makmur dan perwakilan aparat desa Nangsri (Gambar 3).

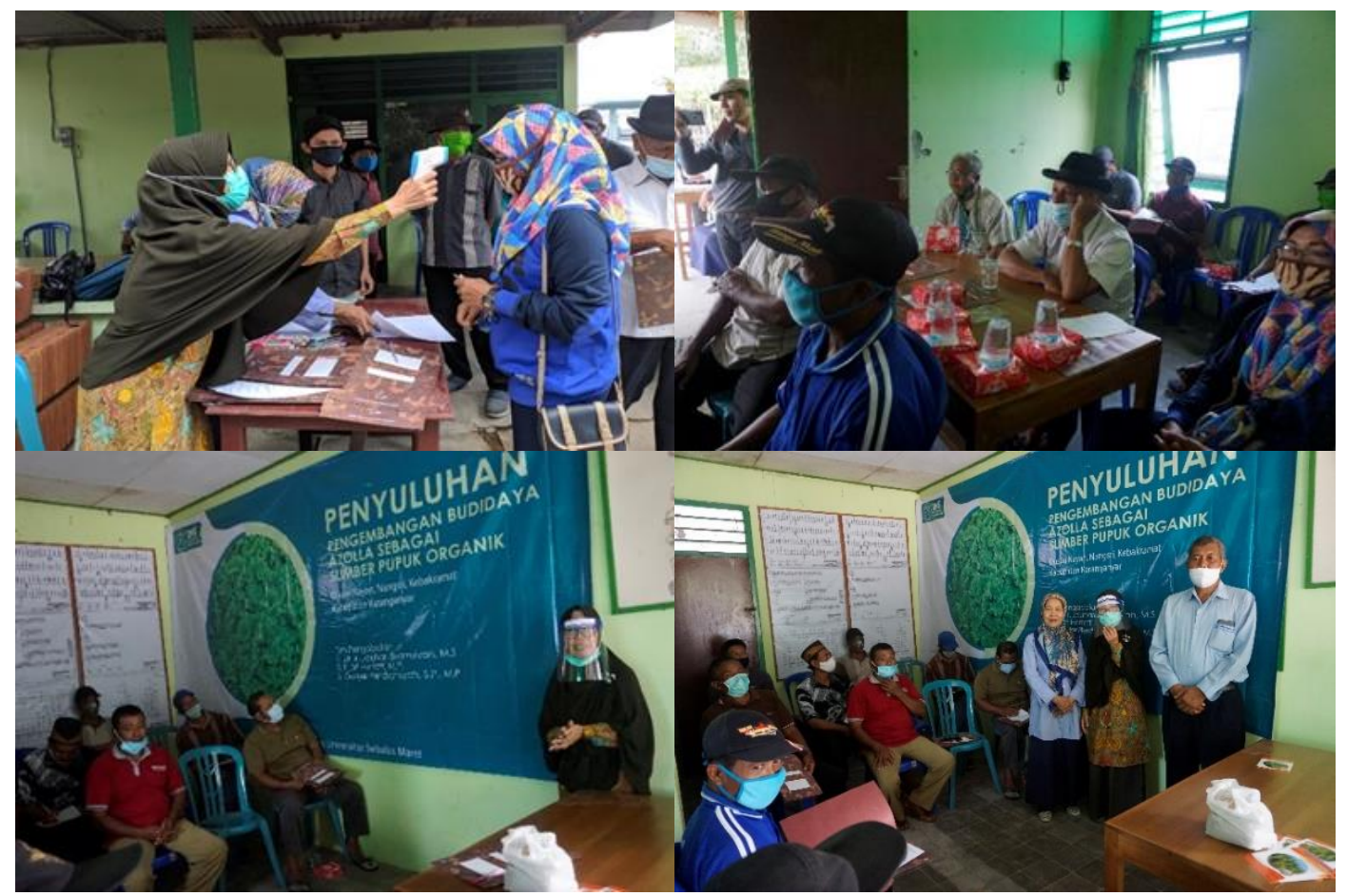

Gambar 3. Kegiatan Penyuluhan

Penyuluhan dipilih sebagai bentuk penyebarluasan hal baru agar Kelompok Tani Tani Makmur dan Margo Mulyo tertarik, berminat dan bersedia melaksanakan kegiatan yang disampaikan kepada masyarakat. Penyuluhan sebagai media komunikasi dan informasi yang dilakukan oleh tim pengabdian guna mentransfer ilmu mengenai azolla, budidaya azolla serta pemanfaatan azolla sebagai pupuk organik. Kegiatan penyuluhan ini dilakukan secara terencana dan terarah, sehingga para petani dapat mengerti, memahami dan tertarik untuk mengikuti seluruh rangkaian kegiatan dengan baik.
Pelaksanaan penyuluhan dimulai dengan melontarkan pertanyaan serta menyebarkan kuesioner untuk mengetahui sejauh mana pengetahuan petani terhadap azolla. Berdasarkan jawaban spontan dari beberapa petani terlihat bahwa masih banyak yang belum mengenal azolla. Beberapa petani mengemukakan baru mendengar saat diperkenalkan nama azolla, dan terasa asing bagi kelompok tani, walaupun dalam bercocok tanam padi azolla ini sering dijumpai pada lahan sawah mereka. Hasil kuesioner saat penyuluhan disajikan pada Gambar 4. 


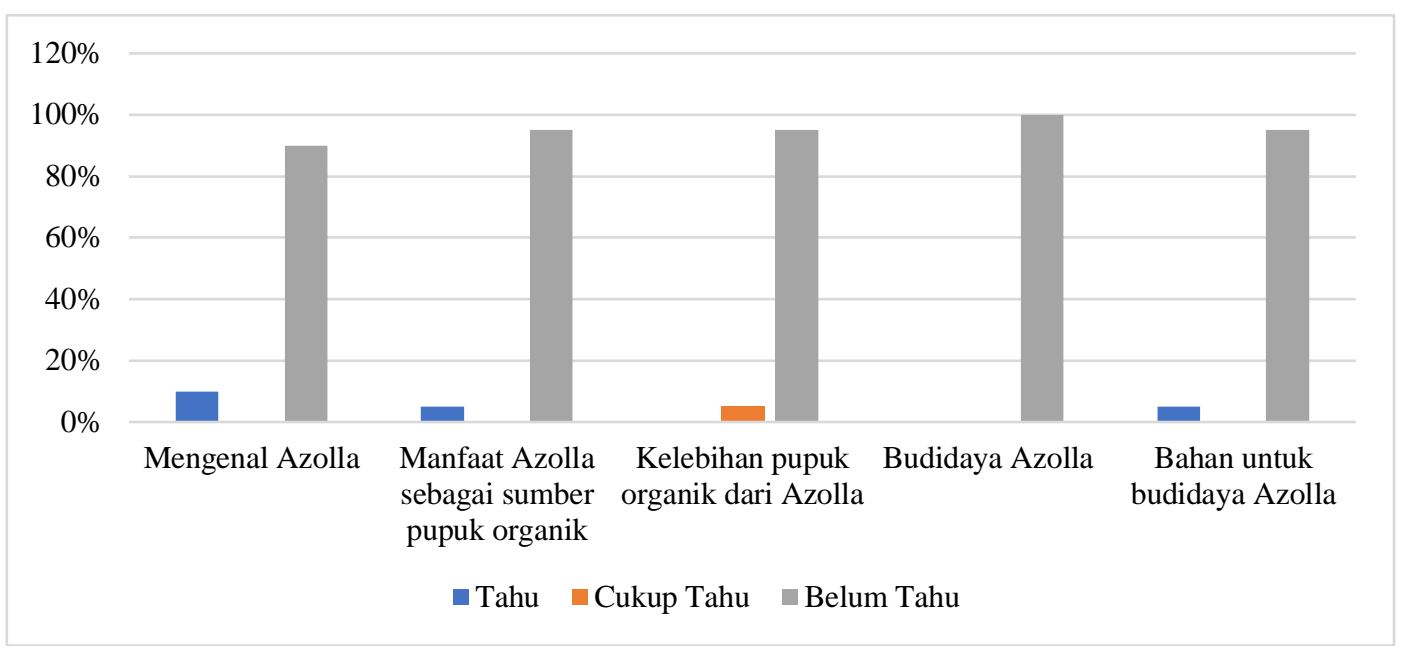

Gambar 4. Diagram Hasil Kuesioner Kegiatan Penyuluhan

Hasil kuesioner menunjukkan bahwa lebih dari $90 \%$ para petani belum mengenal azolla. Sebanyak $95 \%$ petani belum tahu manfaat dari azolla sebagai sumber pupuk organik dan $95 \%$ petani belum tahu kelebihan dari pupuk organik yang terbuat dari Azolla. Pemanfaatan azolla sebagai sumber pupuk organik di lokasi pengabdian memang belum dikenal oleh petani, azolla sendiri dianggap sebagai tanaman liar yang hidup pada lahan persawahan. Azolla merupakan tanaman paku yang dapat digunakan sebagai pupuk organik, sehingga bisa bermanfaat untuk meningkatkan produktivitas tanaman (Sudjana, 2014). Budidaya azolla pun tergolong mudah dengan bahan-bahan yang tersedia banyak di lingkungan sekitar lokasi pengabdian. Berdasarkan hasil kuesioner, $>90 \%$ petani tidak mengetahui bagaimana membudidayakan azolla dan bahan yang digunakannya. Azolla membutuhkan waktu 15 hari atau 2 minggu untuk dapat dipanen. Pupuk kandang dan air merupakan bahan yang digunakan dalam budidaya azolla. Nutrisi yang digunakan untuk pertumbuhan azolla yaitu pupuk kandang, kompos atau pupuk mol. Penggunaan pupuk kandang kuda dan ayam terhadap pertumbuhan Azolla microphylla mengalami peningkatan setiap minggunya (Surdina et al., 2016).

Penggunaan azolla sebagai pupuk organik sangat tepat, karena terdapat beberapa kandungan yang dapat mempengaruhi pertumbuhan tanaman. Azolla merupakan tanaman paku yang memiliki kemampuan bersimbiosis dengan bakteri biru dan bakteri hijau anabaena azzolae yang dapat mengikat unsur nitrogen dari udara. Kemampuan tersebut menjadikan azolla sebagai pupuk hijau terbaik yang dapat digunakan di lahan sawah maupun lahan kering. Penyuluhan mengenai pupuk organik dari azolla sangat diperlukan oleh masyarakat dan merupakan hal yang menarik untuk disampaikan, hal ini terlihat dari peran aktif para peserta yang hadir.

\section{Pelatihan Budidaya Azolla}

Kegiatan pelatihan budidaya azolla dilakukan setelah penyuluhan, yang diawali dengan melakukan persiapan dan koordinasi dengan perwakilan kelompok tani untuk menentukan waktu dan tempat pelatihan. Kegiatan diawali dengan pembuatan bak atau kolam untuk budidaya azolla (Gambar 5).

Tim pengabdian bekerjasama dengan perwakilan kelompok tani membuat tempat yang akan dijadikan sebagai media untuk budidaya azolla. Selama proses pelatihan muncul berbagai pertanyaan yang dilontarkan oleh petani terkait dengan azolla. Kegiatan lain yang dilakukan dalam persiapan adalah mempersiapkan bahan-bahan yang diperlukan seperti bibit azolla, pupuk kandang serta alat yang diperlukan seperti ember dan selang.

Pelatihan budidaya azolla dimaksudkan untuk mempraktekan hasil dari kegiatan penyuluhan sebelumnya. Pelatihan ini dilakukan untuk memperkaya wawasan dan meningkatkan keterampilan para petani dalam budidaya azolla. Kegiatan ini terlebih dahulu dilakukan dengan pemutaran video mengenai budidaya azolla pada beberapa media (kolam tanah maupun terpal, nampan dan ember), setelah itu para petani mempraktekannya pada kolam terpal yang sebelumnya sudah dipersiapkan. 


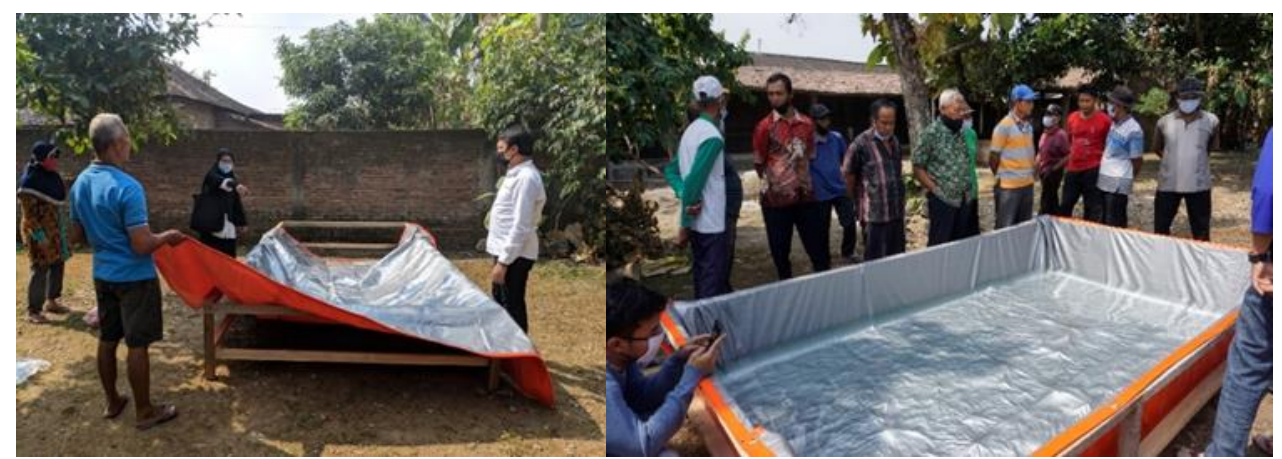

Gambar 5. Pembuatan Kolam Budidaya Azolla

Praktek budidaya azolla dimulai mengisi bak/kolam dengan air setinggi tiga perempat kedalaman bak. Selanjutnya pupuk kandang dilarutkan ke dalam air, diaduk dan dimasukkan ke dalam bak. Pupuk kandang dan air pada pelatihan ini dijadikan sebagai media sekaligus nutrisi untuk pertumbuhan azolla, kemudian bibit azolla disebarkan di atas media tersebut.

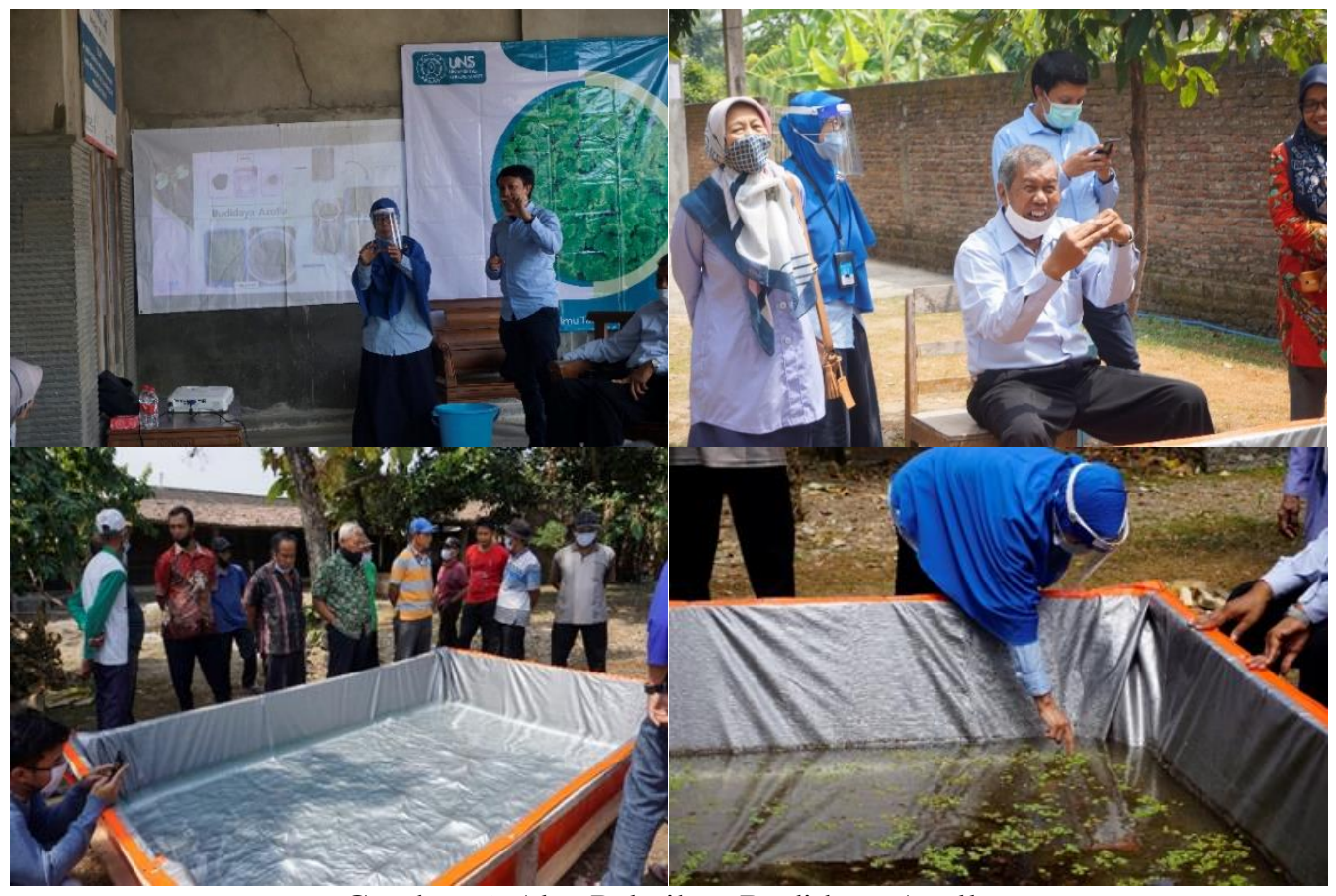

Gambar 6. Alur Pelatihan Budidaya Azolla

Selanjutnya peserta tersebut melakukan perawatan atau pemeliharaan sampai azolla tersebut siap untuk dipanen. Azolla sendiri memang banyak manfaatnya selain untuk pupuk organik juga dapat dijadikan sebagai pakan ternak.

Evaluasi kegiatan pengabdian dilakukan dengan $F G D$ yang dihadiri oleh anggota Kelompok tani Margo Mulyo, Tani Makmur dan aparat desa Nangsri (Gambar 9). Evaluasi ini dilakukan untuk mengukur ketertarikan petani dalam mengembangkan budidaya azolla ini, dengan harapan nantinya bisa menekan biaya pupuk yang digunakan dalam kegiatan pertanian. Dalam kegiatan $F G D$ juga dilakukan pemberian kuesioner ketertarikan kegiatan pelatihan budidaya azolla. Hasil kuisioner menunjukkan bahwa mayoritas petani $(90 \%)$ mengetahui potensi dan manfaat serta tertarik melanjutkan dan mengembangkan budidaya azolla secara mandiri. Mudahnya cara budidaya dan bahan yang digunakan serta pemeliharaan menjadi daya tarik para petani dalam mengembangkan azolla ini, selain itu modal yang diperlukan untuk budidaya azolla tergolong rendah. Manfaat yang bisa dirasakan oleh petani yaitu azolla sebagai pupuk organik mampu meningkatkan serapan $\mathrm{N}$ yang penting untuk pertumbuhan tanaman. Hasil penelitian (Arafah et al., 2017) menunjukkan penggunaan Azolla 
pada budidaya padi dengan kondisi salinitas tanah tinggi dapat meningkatkan serapan $\mathrm{N}$ dan mempengaruhi bobot kering tanaman padi. Ketertarikan petani tidak hanya sebatas manfaat azolla sebagai pupuk organik, tetapi azolla sebagai pakan ternak. Sebagian para petani di lokasi kegiatan pengabdian memiliki beberapa ternak, dengan adanya azolla tentu dapat menekan biaya untuk pakan ternak, hal ini senada dengan penelitian (Sudadi \& Suryono, 2018) yang menyebutkan bahwa penggunaan azolla sebagai pakan konsentrat akan mengurangi jumlah pakan lele sehingga mampu menekan biaya pakan dan usaha tani lele. Menurut Tarigan \& Manalu (2019) Azolla pinnata memiliki kandungan asam amino esensial, protein, vitamin $\mathrm{B} 12$, vitamin $\mathrm{A}$, betacarotene dan mineral (kalsium, fosfor, kalium, zat besi, magnesium). Kandungan dalam azolla ini dapat bermanfaat untuk pertumbuhan ternak. Hasil kuesioner tentang ketertarikan petani mengembangkan azolla disajikan pada Gambar 7.

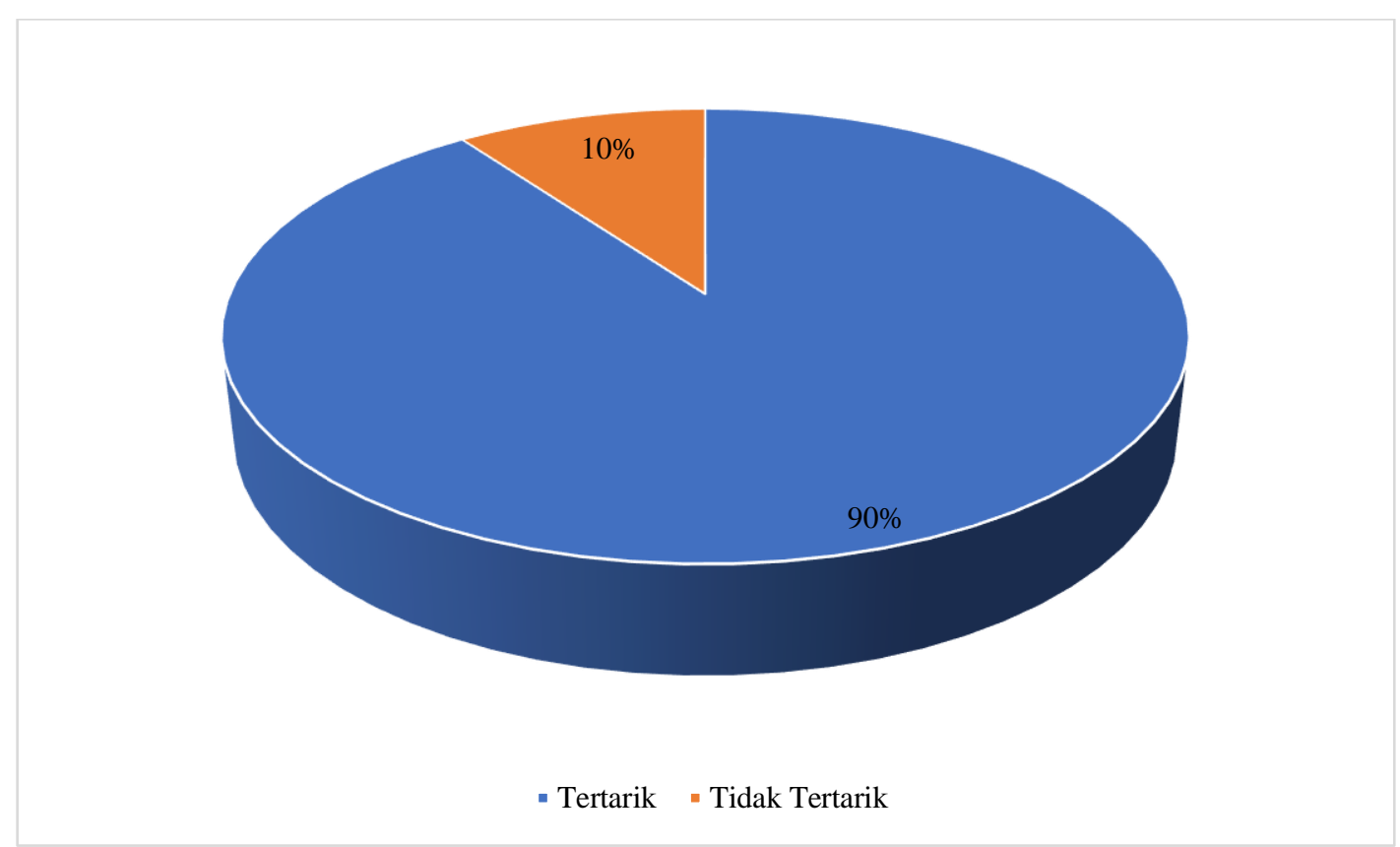

Gambar 7. Diagram Ketertarikan Petani dalam Budidaya Azolla

Pengetahuan petani tentang budidaya azolla dan manfaatnya sebagai pupuk organik meningkat seiring dengan berakhirnya kegiatan ini. Pengenalan budidaya azolla dinilai penting untuk pengembangan pertanian organik yang bersumber dari sumberdaya lokal. Kondisi tersebut terlihat dari antusiasme petani dalam berdiskusi serta menanyakan berbagai hal yang terkait dengan Azolla. Hasil kegiatan yang diukur dengan kuesioner menunjukkan bahwa setelah dilakukan penyuluhan dan pelatihan budidaya azolla sebanyak $90 \%$ petani mengetahui manfaat azolla sebagai sumber pupuk organik, $80 \%$ petani mengetahui kelebihan azolla, dan lebih dari $80 \%$ petani mengetahui cara budidaya dan bahan yang digunakan dalam budidaya azolla (Gambar 8). Hal ini merupakan indikator bahwa transfer ilmu dan teknologi yang sudah dilakukan dapat diterima dengan baik oleh petani. Petani atau peserta dalam kegiatan ini sudah mempunyai gambaran yang jelas tentang budidaya azolla dan usaha mengelolanya. Sebagian besar petani akan berusaha untuk memulai budidaya azolla secara mandiri kedepannya. Hasil kuesioner tentang pemahaman petani setelah dilakukan kegiatan penyuluhan dan pelatihan budidaya azolla dapat dilihat pada Gambar 8 . 


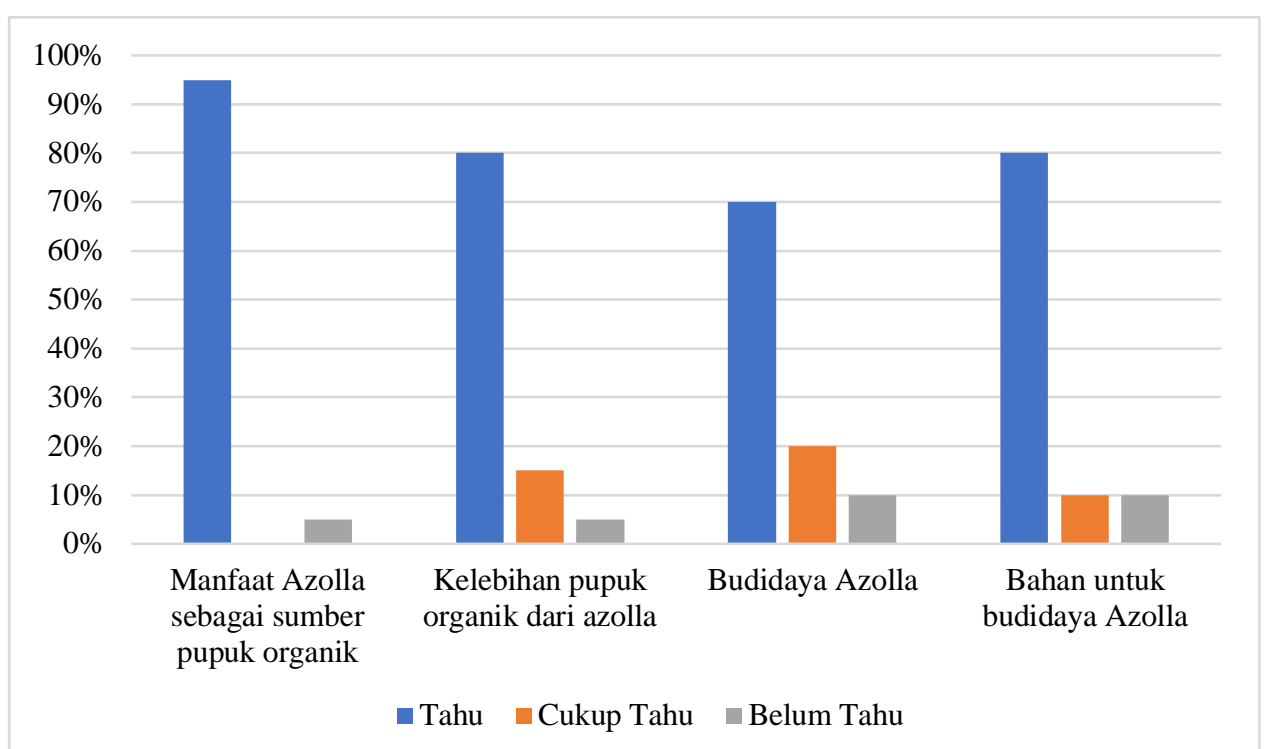

Gambar 8. Diagram Pengetahuan Petani setelah dilakukan Penyuluhan dan Pelatihan budidaya Azolla.

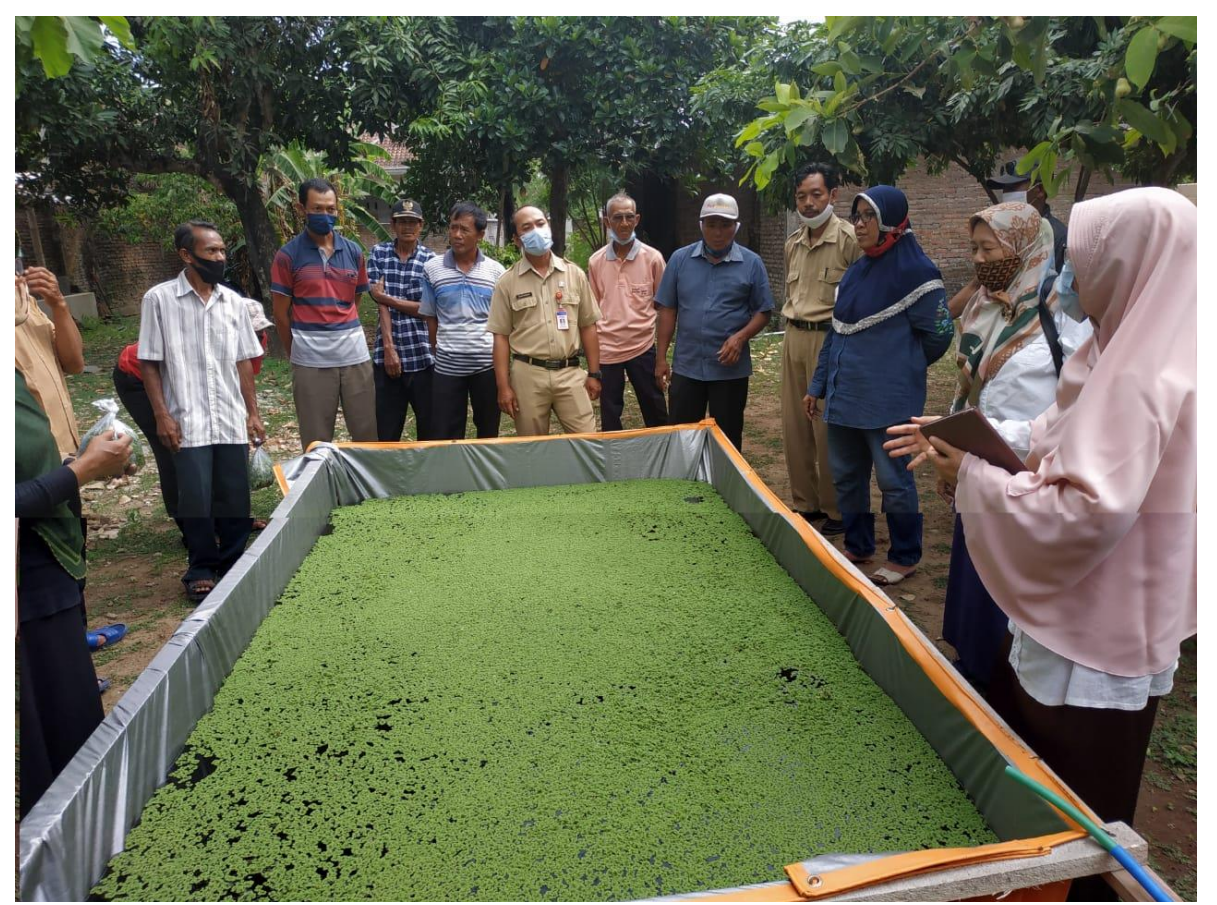

Gambar 9. FGD yang dilakukan oleh Tim Pengabdian, Aparat Desa dan Kelompok Tani

\section{KESIMPULAN}

Kegiatan pengabdian dilakukan melalui penyuluhan, pelatihan dan evaluasi. Kegiatan pengabdian dalam pengembangan pertanian organik yang ramah lingkungan menggunakan sumberdaya lokal yaitu azolla. Pengetahuan petani tentang azolla dan manfaatnya sebagai sumber pupuk organik sebelum dilakukan penyuluhan masih rendah $(<20 \%)$. Setelah kegiatan pengabdian ini, pengetahuan dan pemahaman petani tentang potensi dan manfaat budidaya azolla meningkat serta ketertarikan petani terhadap budidaya azolla secara mandiri mencapai $90 \%$. Azolla merupakan sumber pupuk organik yang dapat menekan penggunaan pupuk anorganik atau sintetik.

\section{UCAPAN TERIMA KASIH}

Ucapan terima kasih disampaikan kepada Institusi Universitas Sebelas Maret yang telah memberikan dukungan dana melalui PNBP 2020. Kepada kelompok tani Margomulyo dan Tani Makmur serta Kepala desa Nayan dan jajarannya, sehingga kegiatan ini bisa terlaksana. 


\section{DAFTAR PUSTAKA}

Arafah, M. S., Setiawati, M. R., \& Nurbaity, A. (2017). Pengaruh pupuk organik (Azolla pinnata) terhadap C-organik tanah, serapan $\mathrm{N}$ dan bobot kering tanaman padi (Oryza sativa L.) pada tanah dengan tingkat salinitas tinggi. Jurnal Agroekoteknologi, 9(1), 9-16.

Bhuvaneshwari, K., \& Kumar, A. (2013). Agronomic potential of the association Azolla - Anabaena. Science Research Reporter.

Gunawan, I. (2014). Kajian peningkatan peran azolla sebagai pupuk organik kaya nitrogen pada padi sawah. Jurnal Penelitian Pertanian Terapan, 14(2), 134-138. https://doi.org/http://dx.doi.org/10.25181/j ppt.v14i2.151

Hendrarti, E., Sopandie, D., Idris, K., \& Sisworo, E. L. (1998). Pengaruh lapisan azolla terhadap pertumbuhan, produksi dan efisiensipenggunaan pupuk urea bertanda $15 \mathrm{~N}$ pada padi sawah. Penelitian Dan Pengembangan Aplikasi Isotop Dan Radiasi, 115-121.

Jeanne, M. P. (2010). Pemanfaatan azolla sebagai pupuk organik pada budidaya padi sawah. Warta Wiptek, 36, 68-72.

Pereira, A. L., Monteiro, B., Azevedo, J., Campos, A., Osório, H., \& Vasconcelos, V. (2015). Effects of the naturally-occurring contaminant microcystins on the Azolla filiculoides-Anabaena azollae symbiosis. Ecotoxicology and Environmental Safety. https://doi.org/10.1016/j.ecoenv.2015.04.0 08

Rasjid, H., Siswoyo, E. L., Wemay, Y., \& Sisworo, W. H. (2000). Efisiensi $N$-urea pada padisawah yang diaplikasi dengan azolla. 139-144.

Setiawati, M. R., Herdiyantoro, D., Damayani, M., \& Suryatmana, P. (2019). Analisis C, $\mathrm{N}, \mathrm{C} / \mathrm{N}$ ratio tanah dan hasil padi yang diberi pupuk organik dan pupuk hayati berbasis azolla pada lahan sawah organik. Soilrens, 16(2), 30-36. https://doi.org/10.24198/soilrens.v16i2.20 857

Soedharmo, G. G., Tyasmoro, S. Y., \& Sebayang, husni thamrin. (2016). Pengaruh pemberian pupuk azolla dan pupuk N pada tanaman padi (Oryza sativa L.) varietas INPARI 13. Jurnal Produksi Tanaman, 4(2), 145-152.

Sudadi, S., \& Suryono, S. (2018). Pemanfaatan azolla sebagai sumber pakan pada budidaya sistem ganda azolla-lele. Caraka Tani: Journal of Sustainable Agriculture, 31(2), 114. https://doi.org/10.20961/carakatani.v31i2. 11992

Sudjana, B. (2014). Penggunaan azolla untuk pertanian berkelanjutan. Jurnal Ilmiah Solusi, 1(2), 72-81.

Supartoto, Widyasunu, P., Rusdiyanto, \& Santoso, M. (2012). Eksplorasi potensi Azolla microphylla dan Lemna Polyrhizza sebagai produsen biomas bahan pupuk hijau, pakan itik dan ikan. Prosiding Seminar Nasional.

Surdina, E., El-rahimi, S. A., \& Hasri, I. (2016). Pertumbuhan Azolla microphylla dengan kombinasi pupuk kotoran ternak. Jurnal Ilmiah Mahasiswa Kelautan Dan Perikanan Unsyiah, 1(3), 298-306.

Syamsiyah, J., Sunarminto, B. H., \& Mujiyo, M. (2018). Potensi azolla sebagai substitusi pupuk kandang pada budidaya padi organik. Caraka Tani: Journal of Sustainable Agriculture, 31(2), 102. https://doi.org/10.20961/carakatani.v31i2. 11956

Tarigan, D. M. S., \& Manalu, D. S. T. (2019). Azolla Pinnata segar sebagai pakan alternatif untuk mengurangi biaya produksi ayam broiler. Jurnal Agrisep, 18(1), 177186.

https://doi.org/10.31186/jagrisep.18.1.177 $-186$ 